\title{
Evaluation of equipment support capability of armored mechanized troops under Information War
}

\author{
Li-Na Chen \\ 31008 Unit, PLA, BeiJing, 100000, China \\ Email:9309806@qq.com
}

\begin{abstract}
Keywords: Information;Equipment guarantee;Evaluation
Abstract: Along with the information technology rapid development in social each domain, also has been widely used in military operations, caused the significant changes to the way the military operations, but also to the integration of modern war, precise, intelligent direction development, equipment support ability to become a key factor of war, the outcome of the paper from the present conditions of the armored mechanized force support, build the evaluation index system of equipment support ability, and by using the G1 method gives index weight and the gray numerical example analyzed, provides a quantitative armor equipment support ability evaluation model, enrich the theoretical framework.
\end{abstract}

\section{Introduction}

With the increase of our country's economic strength, great achievements have been made in equipment support construction, especially infrastructure construction and weaponry development in our army. But compared with the information war, the armored troops, as the main arms of the army, still have great deficiencies in the information level of the equipment support. With the increasing dependence on equipment in modern warfare, it is urgent to strengthen the equipment support capability. It is of great practical significance to analyze and study the equipment support capability under the condition of information warfare.

The evaluation of equipment support capability is a multi index evaluation problem. Many scholars have studied it, including analytic hierarchy process (AHP)[1], fuzzy comprehensive evaluation[2], grey clustering and grey correlation[3]. The above scholars have contributed to the theoretical and practical research on the equipment support capability of our army. However, there are some shortcomings in the study. With the importance of information warfare becoming more and more prominent, the evaluation of equipment support capability is rarely studied in the information war. The above evaluation methods, such as analytic hierarchy process (AHP), have some shortcomings, and there is no numerical example to verify them. On the basis of the above research, through the improvement of AHP method, the index weight is determined, and the grey system theory is used to analyze the example.

\section{Establishment of influencing factors}

Technical support of mechanized equipment in modern warfare is very important. Faced with heavy tasks, high technical requirements, complex content and other requirements, It not only includes command decision-making ability, but also includes the management ability of resource guarantee and maintenance support. According to the characteristics of information warfare and the reality of equipment technology support, the equipment is more streamlined, flexible and effective, and the following factors are analyzed as follows:

\section{(1) Resource support capability}

Equipment resource is an important part of equipment support for armored mechanized troops. Without resource protection, other technical support will be impossible. Equipment automation system is the main characteristic of equipment technical support under the condition of information warfare. Modularization of equipment support force is realized by optimizing combination, to achieve integrated support effectiveness, and to provide fine protection services to combat troops, including human, financial, material and so on. So as to meet the needs of the security to the maximum extent. 
(2) Maintenance support capability

Maintenance support is the main component of equipment support for armored mechanized troops. The capability of maintenance support determines the quality of equipment support of armored mechanized troops. Under the condition of modern warfare, more information technology is needed as a support.

The equipment maintenance needs to overcome the limitations of traditional maintenance closed, make full use of information technology to implement remote maintenance capability( including remote expert diagnostics, remote maintenance components ), achieve precise positioning and instant delivery using artificial intelligence system, construction and maintenance support system, lay the foundation for improving the ability of maintenance.

(3) Command decision making ability

Command decision-making is the primary basis for carrying out armored machinery equipment and technical support. Scientific and efficient command decision-making is the key link to accomplish the task of support. Command decision-making must be scientific and information-based management means to achieve correct decision-making. The premise of decision-making is the collection and calculation of intelligence information and data. By means of relevant computer means, the comprehensive logic judgment can be realized and the best scheme can be worked out. On this basis, we will carry out the mobilization of defense and complete the task of security.

Table1 Equipment support capability evaluation index system

\begin{tabular}{|c|c|c|}
\hline \multirow{10}{*}{$\begin{array}{l}\text { Evaluation of equipment support } \\
\text { capability of armored mechanized } \\
\text { troops under Information War }\end{array}$} & First level index & Second level index \\
\hline & \multirow{3}{*}{$\begin{array}{ll}\text { Resource } & \text { support } \\
\text { capability }\left(x_{1}\right) & \end{array}$} & $\begin{array}{l}\left(x_{11}\right) \text { Equipment automation } \\
\text { system }\end{array}$ \\
\hline & & $\begin{array}{l}\left(x_{12}\right) \text { Optimize organization } \\
\text { ability }\end{array}$ \\
\hline & & $\left(x_{13}\right)$ Fine service ability \\
\hline & \multirow{3}{*}{$\begin{array}{l}\text { maintenance } \quad \text { support } \\
\text { capacity }\left(x_{2}\right)\end{array}$} & $\begin{array}{l}\left(x_{21}\right) \text { Remote maintenance } \\
\text { capability }\end{array}$ \\
\hline & & $\begin{array}{l}\left(x_{22}\right) \text { Artificial intelligence } \\
\text { system }\end{array}$ \\
\hline & & $\begin{array}{l}\left(x_{23}\right) \text { Maintenance support } \\
\text { system }\end{array}$ \\
\hline & \multirow{3}{*}{$\begin{array}{l}\left(x_{3}\right) \text { Command and } \\
\text { decision ability }\end{array}$} & $\begin{array}{l}\left(x_{31}\right) \text { Information collection } \\
\text { calculation }\end{array}$ \\
\hline & & $\begin{array}{l}\left(x_{32}\right) \text { Synthetic logical } \\
\text { judgment }\end{array}$ \\
\hline & & $\begin{array}{l}\left(x_{33}\right) \text { Defense mobilization } \\
\text { capability }\end{array}$ \\
\hline
\end{tabular}

\section{Determine the weight of evaluation index}

(1) Evaluation index weight based on G1 method

Analytic hierarchy process (ahp) is a kind of important method to ascertain the weight of evaluation index, but does not meet the consistency conditions has been the analytic hierarchy process (ahp)[4], the problems facing flood flow, ju-liang jin[5], M a W a Y[6], eigenvector method using genetic algorithm to improve the consistency of analytic hierarchy process (ahp), but did not fundamentally change the analytic hierarchy process (ahp), a defect. The G1 method does not need 
to construct a judgment matrix[7]. The importance of the index can be determined by the following formula, and the weight of each index can be determined. The following is the G1 method to determine the index weight step.

(1)Determine the importance of indicators

Using the $x_{i}(i=1,2 \ldots n)$ magnitude of the importance of the indicators, Remember $x_{i} \geq x_{j}$ that the importance of representation $x_{i}$ and $x_{j}$ is greater than or equal to both. Sort of the importance of $x_{i}$, Remember $x_{i}^{*}$ is the first index after sorting, So there are $x_{1}^{*}>x_{2}^{*} \ldots>x_{n}^{*}$, This is the formula for sorting $x_{i}$ by importance.

(2) The relative importance of two indexes is given

The magnitude of the magnitude of $x_{k-1}$ and $x_{k}$ is measured in $(k=2,3 \ldots n)$, The value of $x_{k-1}$ and $x_{k}$ is shown in table 2 of the assignment of $r_{k}$.

Table 2 comparison between indicators based on G1 method

\begin{tabular}{ccccccc}
\hline $\begin{array}{c}\text { Degree of } \\
\text { importance }\end{array}$ & $\begin{array}{c}\text { Equally } \\
\text { important }\end{array}$ & $\begin{array}{c}\text { weak } \\
\text { importance }\end{array}$ & $\begin{array}{c}\text { General } \\
\text { important }\end{array}$ & $\begin{array}{c}\text { Obviously } \\
\text { important }\end{array}$ & $\begin{array}{c}\text { Highly } \\
\text { important }\end{array}$ & $\begin{array}{c}\text { absolute } \\
\text { importance }\end{array}$ \\
\hline$r_{i}$ & 1.0 & 1.2 & 1.4 & 1.6 & 1.8 & 2.0 \\
\hline
\end{tabular}

(3) The calculation of weight coefficient

According to the literature [5], If the rational assignment that the expert gives $r_{k}$ satisfies $r_{k-1} * r_{k}>1$, then $w_{n}=\left[1+\sum_{k=2}^{n} \prod_{i=k}^{n} r_{k}\right], w_{k-1}^{*}=w_{k}^{*} * r_{k}, k=(n, n-1 \ldots 2)$ 。

\section{(2) Evaluation index weight calculation}

According to the evaluation of the systematic, scientific, objective principle, invite equipment industry 10 experts to rate the importance of each relevant indicators, according to the results of the expert scoring ability to get resources security $x_{1}$, maintenance support ability $x_{2}$, the importance of the command decision-making ability $x_{3}$ between three primary index size degree for $x_{3}>x_{1}>x_{2}$, In order of importance, the order relation of the three primary indexes can be recorded as $x_{1} *>x_{2} *>x_{3} *$, The ratio of the importance of each index is $r_{2}=\frac{w_{1}}{w_{2}}=1.4, r_{3}=\frac{w_{2}}{w_{3}}=1.2$,

According to the formula in (1), the weight of the primary index can be calculated, and the weight of the secondary index can be calculated, as shown in table 3.

Table 3 Weight of equipment guarantee ability index

\begin{tabular}{|c|c|c|c|c|}
\hline $\begin{array}{l}\text { First level } \\
\text { index }\end{array}$ & $\begin{array}{l}\text { Primary index } \\
\text { weight }\end{array}$ & $\begin{array}{l}\text { Second level } \\
\text { index }\end{array}$ & $\begin{array}{c}\text { Secondary index } \\
\text { weight }\end{array}$ & $\begin{array}{l}\text { The total weight } \\
\text { of the secondary } \\
\text { index }\end{array}$ \\
\hline \multirow{3}{*}{$\begin{array}{l}\text { Resource } \\
\text { support } \\
\text { capability }\end{array}$} & \multirow{3}{*}{0.3093} & $\begin{array}{l}\text { Equipment } \\
\text { automation } \\
\text { system }\end{array}$ & 0.3956 & 0.1224 \\
\hline & & $\begin{array}{c}\text { Optimize } \\
\text { organization } \\
\text { ability }\end{array}$ & 0.3297 & 0.102 \\
\hline & & $\begin{array}{c}\text { Fine service } \\
\text { ability }\end{array}$ & 0.2747 & 0.085 \\
\hline
\end{tabular}


Table 3, cont.

\begin{tabular}{|c|c|c|c|c|}
\hline \multirow{4}{*}{$\begin{array}{c}\text { Maintenance } \\
\text { support } \\
\text { capacity }\end{array}$} & 0.2577 & $\begin{array}{c}\text { Remote } \\
\text { maintenance } \\
\text { capability }\end{array}$ & 0.3684 & 0.095 \\
\cline { 3 - 5 } & $\begin{array}{c}\text { Artificial } \\
\text { intelligence } \\
\text { system }\end{array}$ & 0.3684 & 0.095 \\
\cline { 3 - 5 } & \multirow{2}{*}{$\begin{array}{c}\text { Maintenance } \\
\text { support system }\end{array}$} & 0.2632 & 0.0768 \\
\hline \multirow{2}{*}{$\begin{array}{c}\text { Command and } \\
\text { decision } \\
\text { ability }\end{array}$} & $\begin{array}{c}\text { Information } \\
\text { collection } \\
\text { calculation }\end{array}$ & 0.3125 & 0.1353 \\
\cline { 3 - 5 } & $\begin{array}{c}\text { Synthetic logical } \\
\text { judgment }\end{array}$ & 0.375 & 0.1624 \\
\cline { 3 - 5 } & $\begin{array}{c}\text { Defense } \\
\text { mobilization } \\
\text { capability }\end{array}$ & 0.3125 & 0.1353 \\
\hline
\end{tabular}

\section{Construction of the evaluation model of equipment technical support capability based on grey theory}

(1) Establishment of evaluation model of equipment technical support capability

The grey system theory is put forward by Chinese scholars, professor deng julong, mainly through the study of known information [8], extract the valuable information to achieve a correct description of the research object, using the theory of grey system evaluation steps are [9]:

(1) Sample matrix data acquisition

The evaluation sample matrix was evaluated by using the expert scoring method, and the evaluation of each indicator was evaluated by x experts for $j$ secondary indexes, So the sample matrix is $B=b_{i j(9 \times 5)}$ 。 The evaluation of equipment technical guarantee ability is divided into four grades. The evaluation group is \{poor, general, good, good $\}$, and the corresponding score is $\{1,2,3,4\}$ 。

(2) Determine the albino function

$$
B=\left\{\begin{array}{cccc}
b_{11} & b_{12} & \ldots & b_{15} \\
b_{21} & b_{22} & \ldots & b_{25} \\
\ldots & \ldots & \ldots & \ldots \\
b_{91} & b_{92} & \ldots & b_{95}
\end{array}\right\}
$$

Each grey class corresponds to a grey number (remember to do it, in a certain range or certain value within a set of general number of uncertain destiny), each one different values within the scope of grey numeral "preference" degree by whitenization weight function, different grey whitenization weight function of such as shown in table 4. 
Table 4 Whitening weight function table of different ash classes

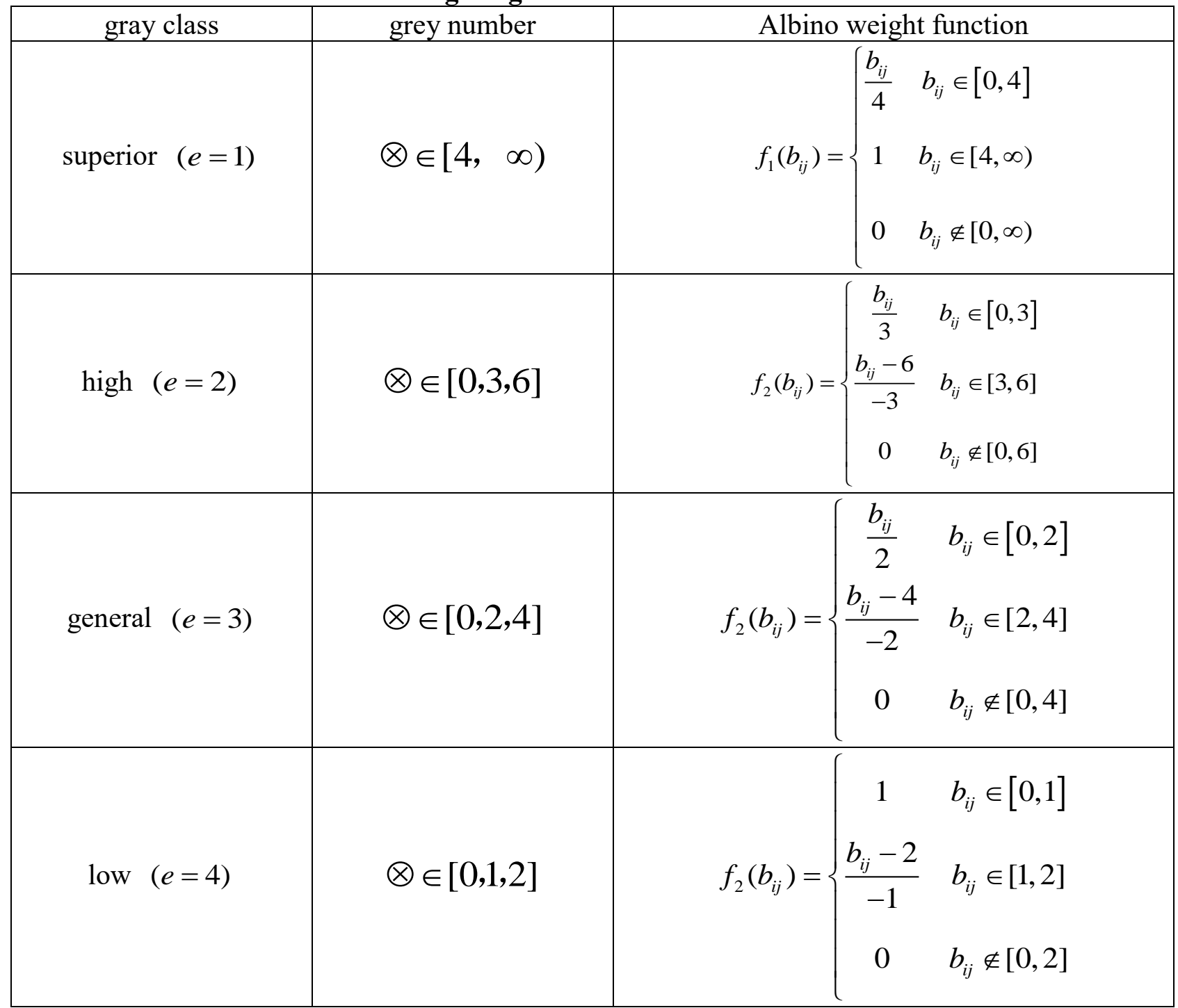

From table 3, we can determine the whitening weight function of the four types of grey classes, and then we can evaluate the white value of $b_{i j}$ in different grey classes by the calculation formula of the white power function $f_{e}\left(b_{i j}\right), i=1,2, \ldots, 18 ; j=1,2,3,4,5$, In the second grade, the first of the indexes of the first category is $e$,

$$
c_{i}^{e}=\sum_{j=1}^{5} f_{e}\left(b_{i j}\right)
$$

At the same time, the total grey evaluation coefficient of evaluation index $i$ is obtained

$$
C_{i}=\sum_{e=1}^{4} \sum_{j=1}^{5} f_{e}\left(b_{i j}\right)
$$

By formula and formula, the grey evaluation weight of the index $i$ - class $e$ grey class is evaluated

$$
r_{i}^{e}=\frac{c_{i}^{e}}{C_{i}}
$$

Therefore, the evaluation index's grey evaluation weight matrix is 
(3) Comprehensive evaluation.

$$
R=\left(r_{i}^{e}\right)_{18 \times 4}=\left(\begin{array}{cccc}
r_{1}^{1} & r_{1}^{2} & r_{1}^{3} & r_{1}^{4} \\
r_{2}^{1} & r_{2}^{2} & r_{2}^{3} & r_{2}^{4} \\
\vdots & \vdots & \vdots & \vdots \\
r_{9}^{1} & r_{9}^{2} & r_{9}^{3} & r_{9}^{4}
\end{array}\right)
$$

According to the gray evaluation matrix mentioned above, the weight of each index of the first and second level is determined by the combination of the G1 method, which is the weight vector of the secondary index relative to the whole

$$
\begin{aligned}
A=x_{i} * y_{i}=\left(x_{1} y_{1}, x_{1} y_{2},\right. & x_{2} y_{3}, x_{2} y_{4}, x_{2} y_{5}, x_{2} y_{6}, x_{2} y_{7}, x_{3} y_{8}, x_{3} y_{9}, x_{3} y_{10}, \\
& \left.x_{4} y_{11}, x_{4} y_{12}, x_{5} y_{13}, x_{5} y_{14}, x_{6} y_{15}, x_{6} y_{16}, x_{6} y_{17}, x_{6} y_{18}\right)
\end{aligned}
$$

The comprehensive evaluation matrix is obtained

$$
Q=A R=\left(x_{1} y_{1}, x_{1} y_{2}, x_{1} y_{3}, x_{2} y_{4}, x_{2} y_{5}, x_{2} y_{6}, x_{3} y_{7}, x_{3} y_{8}, x_{3} y_{9}\right)\left(\begin{array}{cccc}
r_{1}^{1} & r_{1}^{2} & r_{1}^{3} & r_{1}^{4} \\
r_{2}^{1} & r_{2}^{2} & r_{2}^{3} & r_{2}^{4} \\
\vdots & \vdots & \vdots & \vdots \\
r_{18}^{1} & r_{18}^{2} & r_{18}^{3} & r_{18}^{4}
\end{array}\right)
$$

Because the value vector for the grey class is $E=(4,3,2,1)$, Therefore, the comprehensive appraisal value is $Z=Q E^{T}$ 。

(2) example analysis

The existing safeguard team A, the command and decision-making layer decides to carry out the equipment guarantee task, evaluates the various indexes of grade A and the score matrix according to the evaluation by six experts.

$$
\left[\begin{array}{llllll}
3 & 1 & 2 & 2 & 2 & 3 \\
1 & 1 & 1 & 2 & 2 & 1 \\
1 & 1 & 1 & 1 & 2 & 1 \\
1 & 2 & 2 & 2 & 1 & 1 \\
2 & 2 & 1 & 1 & 1 & 2 \\
3 & 2 & 3 & 4 & 2 & 2 \\
4 & 2 & 2 & 2 & 2 & 3 \\
3 & 4 & 2 & 2 & 3 & 3 \\
2 & 3 & 2 & 2 & 3 & 3
\end{array}\right]
$$

\begin{tabular}{|c|c|c|c|c|c|c|c|c|c|}
\hline & $b_{1 j}$ & $b_{2 j}$ & $b_{3 j}$ & $b_{4 j}$ & $b_{5 j}$ & $b_{6 j}$ & $b_{7 j}$ & $b_{8 j}$ & $b_{9 j}$ \\
\hline$f_{1}\left(b_{i j}\right)$ & 3.25 & 2 & 1.75 & 2.25 & 2.25 & 4 & 3.75 & 4.25 & 3.75 \\
\hline$f_{2}\left(b_{i j}\right)$ & 4.333 & 2.667 & 2.333 & 3 & 3 & 4.667 & 4.333 & 5 & 5 \\
\hline$f_{3}\left(b_{i j}\right)$ & 4.5 & 4 & 3.5 & 4.5 & 4.5 & 4 & 4.5 & 5 & 4.5 \\
\hline$f_{4}\left(b_{i j}\right)$ & 1 & 4 & 5 & 3 & 3 & 0 & 0 & 0 & 0 \\
\hline$\sum_{=1} f_{e}\left(b_{i j}\right)$ & 13.083 & 12.667 & 12.583 & 12.75 & 12.75 & 12.667 & 12.583 & 14.25 & 13.25 \\
\hline
\end{tabular}

According to the calculation formula of the albino weight function, the whitening weight of the secondary indexes under different grey categories is shown in table 5.

Table 5 whitening weights under different ash classes 
According to the grey evaluation matrix and the weight of each index, in table 2 can be secondary index evaluation vector and the total evaluation vector, and then can score and total score of each indicator is calculated:

$$
Q=A R=\left(\begin{array}{llll}
0.2150 & 0.2718 & 0.3122 & 0.1290
\end{array}\right)
$$

Then the comprehensive evaluation value of team $\mathrm{A}$ is obtained

$$
Z=Q E^{T}=\left[\begin{array}{llll}
0.2150 & 0.2718 & 0.3122 & 0.1290
\end{array}\right]\left[\begin{array}{llll}
4 & 3 & 2 & 1
\end{array}\right]^{T}=2.43
$$

Through the above index weight and evaluation, the general equipment support technology for the score of A level, at the same time you should see A on resources should be strengthened to safeguard and maintenance support ability, raise the level of its information operations.

\section{Conclusion}

Paper according to the foreign information war and our actual condition, build the equipment technical support ability evaluation index system, the method based on the G1 given the weight of each level indicators and secondary indicators, and A BaoZhangDui, for example, using the method of grey system theory to you under the condition of informatization equipment support ability was calculated, for armored equipment support ability evaluation of mechanical forces laid A foundation. Through the above research, the following conclusions are obtained:

(1) Strengthen the level of command and decision-making

Through G1 method to determine index weight, the command decision-making level of weight is greater than the resources safeguard and maintenance support ability, should be given, under the same condition decision command, at the same time, resources and various indexes of maintenance support also have a focus, constantly improve the comprehensive ability.

(2) Strengthen evaluation practice

Paper from several aspects to consider armor equipment support ability evaluation index system is constructed, at the grass-roots level should be further practice, validation index is scientific, on the other hand, improve on index exists imperfect aspects, in order to help improve our information warfare capabilities.

\section{Reference}

[1] Saaty.T.L. The analytic hierarchy process [M ] .NewYork:Mcgraw -hill,1980.

[2] WANG Qian.Reflection on Qualified Railway Materials Supplier Management[J].Railway Quality Control, 2015, 43(12): 35-38.

[3] GUO Jin-yu, ZHANG Zhong-bin, SUN Qing-yun.Study and Application of Analytic Hierarchy Process[J]. China Safety Science Journal, 2008, 18(5): 148-153.

[4] Saaty.T.L. The analytic hierarchy process [M ] .NewYork:Mcgraw -hill,1980.

[5] HONG Yuan-yuan, QIU Wan-hua.An Integrated Arithmetic of AHP and GEM[J].Chinese Journal of Man-agement Science, 2000, 8(4): 36-42.

[6] M a W Y . A practical approach modifying pairwise comparison matrices and tow criteria of $\mathrm{m}$ odificatory effectiveness[J] .Journa of Systems Science and Systems Engineering ,1993,2 (4) : 334-338.

[7] WANG Ya-jun, GUO Ya-jun.Analyzing the Contsistency of Comparsion Matrix Based on G1 Method[J]. Chinese Journal of Management Science, 2006, 14(3): 65-70.

[8] MOU Hai-bo, DONG Bo.Study on Reserve Point Location Selection of Railway Emergency Materials[J]. Railway Transport and Economy, 2014, 36(9): 72-75.

[9] ZHI Qing-qing.The Measurement and Cultivation of customer Loyalty of C2C E-commerce based on Gray Evaluation[D].South China University of Technology, 2012. 